\title{
Affinity for glycoproteins of bacteria found in the respiratory tract in cystic fibrosis
}

\author{
B. A. SAGGERS AND DAVID LAWSON \\ From the Pathology Department, Queen Mary's Hospital for Children, Carshalton
}

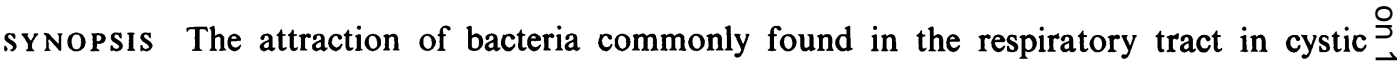
fibrosis to glycoprotein at $p \mathrm{H} 7$ has been studied. The effect of washing on the removal of $\vec{D}$ bacteria from the glycoprotein has also been investigated, and the value of doing both washed and unwashed sputum cultures is discussed.

The relationship between pathogenicity and the bacteria present in a routine sputum culture has been studied by Shiota (1967), who found that true pathogenic bacteria were more abundant in a culture from washed sputum than in a routine culture. Studies in this laboratory have shown that it is possible to increase the yield of Haemophilus influenzae, Streptococcus pneumoniae and, to some extent, Staphylococcus aureus, by this method.

May and Delves (1965) have shown that the ampicillin concentrations in sputum are influenced by the purulence of specimens, and Saggers and Lawson (1968) have demonstrated this relationship with cloxacillin in one case of cystic fibrosis. Bacteria that are embedded in the mucus would be difficult to eradicate with those antibiotics because of poor mucus penetration (Saggers and Lawson, 1966).

A series of experiments is reported here in which a bacteria-glycoprotein system in vitro has been used with a view to investigating the distribution of bacteria in mucus plugs and their attachment thereto.

\section{Materials and Methods}

TEST BACTERIA

These were all fresh isolates from routine cultures of cystic fibrosis sputum and were as follows:

Received for publication 17 July 1969. a non-capsulated strain of $\boldsymbol{H}$. influenzae, single $\sum_{3}$ strains of Klebsiella aerogenes, Pseudomonas aeruginosa, Proteus mirabilis, a coagulase-posi- $\stackrel{\circ}{\varnothing}$ tive staphylococcus, and Strep. pneumoniae.

All the above bacteria were used from over- $\overrightarrow{\vec{B}}$ night nutrient broth cultures grown at $37^{\circ} \mathrm{C} . \frac{3}{3}$ $\mathrm{X}$ and $\mathrm{V}$ factors were added to the broth to support the growth of $H$. influenzae, and $1 \%$ horse blood was added to support the growth of Strep. pneumoniae.

BACTERIAL COUNTS

All dilutions of bacteria and bacteria plus glycoprotein were done in sterile Ringer's solution. The bacteria contained in $0.1 \mathrm{ml}$ volumes of the dilutions were plated in duplicate by the spread plate method. Counts for $K$. N aerogenes, Ps. aeruginosa, and Staph. aureus were done on nutrient agar, $H$. influenzae on $\mathrm{X}$ and V agar, Proteus mirabilis on McConkey $\omega$ agar, and Strep. pneumoniae on horse blood agar.?

Plates showing less than 400 colonies weré not counted. The mean bacterial count was determined from both sets of dilutions.

\section{GLYCOPROTEIN}

The design of the experiments required sterile glycoprotein of a fixed composition. The salivary glycoprotein from the same individual was usedo in all experiments to meet this requirement.0

Mixed saliva was collected into sterile centrifuge tubes cooled in melting ice. The saliva was? 
centrifuged at $1,000 \mathrm{rpm}$ for five minutes to remove any debris and the glycoprotein was precipitated at $p \mathrm{H} 3 \cdot 0-4 \cdot 0$ with $\mathrm{N}$ acetic acid. The glycoprotein was redissolved in sterile Ringer's solution and refractionated with ethyl alcohol at $4{ }^{\circ} \mathrm{C}$ at a final concentration of $64 \%$ $(\mathrm{v} / \mathrm{v})$. The use of ethyl alcohol in the procedure was sufficient to sterilize the glycoprotein. The refractionated glycoprotein was rehydrated in sterile Ringer's solution overnight at $4^{\circ} \mathrm{C}$ and then used.

All experiments in this series were done at $p H$ 7.0. May and Delves (1964) have shown that the $p \mathrm{H}$ of the majority of fresh samples of bronchitic sputum are around this value, and in a limited study of cystic fibrosis sputum we have had similar results.

\section{BACTERIAL CHARGE}

The charge on the test bacteria was investigated at $p \mathrm{H} 7.0$ using low voltage electrophoresis. A glass slide, $7.5 \mathrm{~cm} \times 4.5 \mathrm{~cm}$, was covered with $8 \mathrm{ml}$ of $1 \%$ ion agar (Oxoid) in $0.1 \mathrm{M}$ phosphate/ citrate buffer. A ditch, $60 \mathrm{~mm} \times 3 \mathrm{~mm}$, was cut into the agar and was filled with a suspension of the washed test organism at $1 \times 10^{2}$ organism/ $\mathrm{ml}$ in Ringer's solution. Electrophoresis was run at 6 volts $/ \mathrm{cm}$ for two hours, after which $2 \mathrm{~mm}$ loop samples were taken from the anodic and cathodic ends of the ditch and plated. The charge of the test bacterium was determined by migration in the electrical field.

The general charge on the glycoprotein molecule at $p \mathbf{H} 7.0$ was determined by electrophoresis on cellulose acetate. The glycoprotein was stained by the periodic-acid Schiff method. Endoosmotic flow in these experiments was determined by the migration of $2: 4$ dinitroethanolamine.

ATTACHMENT OF THE BACTERIA TO THE GLY COPROTEIN

Two methods were used: by nephelometry, estimating the bacteria lost from a suspension by attachment to the glycoprotein, and by viable counts of the bacteria attached to the glycoprotein.

\section{By nephelometry}

In this series of experiments density readings were taken by using an EEL nephelometer with an OR2 filter. The supplied standard was set at $100 \%$ transmission.

Twenty millilitres of a suspension of washed bacteria in Ringer's solution was adjusted to give $50 \%$ transmission on the nephelometer. The bacterial suspension was placed at $4^{\circ} \mathrm{C}$ for one hour to ensure that all the bacteria were in the lag phase. Two $9 \mathrm{ml}$ volumes of the suspension were taken; to one was added $1 \mathrm{ml}$ of glycoprotein (test) and to the other
$1 \mathrm{ml}$ of sterile small glass beads (control). The $c$ addition of the glass beads $(1.5 \mathrm{~mm})$ was made $\cong$ to simulate trapping of bacteria by mucus sinking in the bacterial suspension.

The bacterial suspensions were then placed at $\vec{\partial}$ $4^{\circ} \mathrm{C}$ for four hours and then the top $5 \mathrm{ml}$ each of the test and control were read on the nephelo- $\overrightarrow{\bar{S}}$ meter. The control was also diluted $1: 1,1: 5,+\frac{\overrightarrow{0}}{0}$ $1: 10$ with sterile Ringer's solution and read. 든 A total viable count was also done on the control $\frac{\bar{c}}{\bar{s}}$. to enable a graph of the number of bacteria $\widehat{\varnothing}$ per nephelometer reading to be constructed for each organism. The number of organisms कs removed from the suspension by the glycoprotein $\vec{O}$ was calculated from this.

Attempts to run this experiment at $37^{\circ} \mathrm{C}$ were ${ }_{\sigma}^{\omega}$ unsuccessful due to uneven bacterial growth and the tendency for the glycoprotein mass to disintegrate.

\section{By viable count}

Twenty millilitres of a $1 \times 10^{-2}$ dilution of Twenty millilitres of a $1 \times 10^{-2}$ dilution of an 의 stored at $4^{\circ} \mathrm{C}$ for one hour. Nine ml of the bacterial $\vec{\nabla}$ suspension was added to each of two sterile? centrifuge tubes. To one tube was added $1 \mathrm{ml}=$ of glycoprotein (test) and to the other tube $1 \mathrm{ml}$ of Ringer's solution (control). Both tubes. were incubated for four hours at $37^{\circ} \mathrm{C}$ and then treated as follows.

One millilitre was taken and an equal volume of buffered pancreatin solution (Oxoid) added. The mixture was incubated at $37^{\circ} \mathrm{C}$ for 30 min $\underset{\varrho}{\Phi}$ and counted. The results from this were taken $\overrightarrow{\vec{F}}$ as the basic count.

One millilitre of the control was counted without treatment with pancreatin, the remain-? ing $7 \mathrm{ml}$ was then spun for three min at $500 \mathrm{rpm}$ and a $1 \mathrm{ml}$ sample was taken from the top of the? suspension and counted. The percentage of $\frac{\sigma}{3}$ bacteria spun down was estimated and used as a correction factor for the test.

The bacterial suspension was removed from above the glycoprotein with a Pasteur pipette and the glycoprotein was washed once in $3 \mathrm{ml}$ Ringer's solution. The resulting suspension was spun for three min at $500 \mathrm{rpm}$ and the super- N natant was removed. The glycoprotein plug was homogenized using an Atomix and divided into two $0.5 \mathrm{ml}$ portions. To one portion was $\omega$ added $0.5 \mathrm{ml}$ of buffered pancreatin, the mixture was incubated at $37^{\circ} \mathrm{C}$ for $30 \mathrm{~min}$, and counted. The second portion was washed violently with three consecutive $3 \mathrm{ml}$ volumes of Ringer's? solution and then treated as the first portion.

\section{Results}

BACTERIAL CHARGE

The overall charges on the test bacteria were found to be: $H$. influenzae and Strep. pneu- 
moniae, strongly negative; Staph. aureus, negative; $K$. aerogenes, $P$. mirabilis, and $P$ s. aeuruginosa, weakly negative to neutral.

The total charge of the glycoprotein molecule was neutral to weakly positive.

\section{ATTACHMENT OF BACTERIA TO}

GLYCOPROTEIN

The results of the two series of experiments (Tables I and II) have been calculated to give the number of bacteria from a suspension of $1 \times 10^{6}$ organisms that were attached to $1 \mathrm{ml}$ of glycoprotein. Table I (nephelometry) shows that $H$. influenzae, Strep. pneumoniae, and Staph. aureus are more firmly attached to the glycoprotein than the other test organisms.

\begin{tabular}{ll}
\hline $\begin{array}{l}\text { Organisms Supplied at } \\
I \times 10^{6} \text { Organisms } / m l\end{array}$ & $\begin{array}{l}\text { Mean No. of Organisms per } \\
\text { ml of Glycoprotein }\end{array}$ \\
\hline Strep. pneumoniae & $8.0 \times 10^{5}$ \\
H. infuenzae & $6.45 \times 10^{5}$ \\
Staph. aureus & $4.18 \times 10^{4}$ \\
Proteus mirabilis & $5.0 \times 10^{3}$ \\
Ps. aeruginosa & $1.4 \times 10^{3}$ \\
K. aerogenes & $7 \cdot 3 \times 10^{2}$ \\
\hline
\end{tabular}

Table I Attachment of bacteria to glycoprotein at $\mathrm{pH} 7.0$ and a temperature of $4^{\circ} \mathrm{C}$ (by nephelometry)

\begin{tabular}{lll}
\hline $\begin{array}{l}\text { Organism Supplied at } \\
I \times 10^{8} \text { Organisms } / \mathrm{ml}\end{array}$ & $\begin{array}{l}\text { Mean No. of Organisms per } \mathrm{ml} \text { of } \\
\text { Glycoprotein }\end{array}$ \\
\cline { 2 - 3 } & Before Washing & After Washing \\
\hline H. influenzae & $6.45 \times 10^{4}$ & $5.4 \times 10^{4}$ \\
Strep. pneumoniae & $6.25 \times 10^{4}$ & $6.2 \times 10^{4}$ \\
Staph. aureus & $5.7 \times 10^{3}$ & $4.3 \times 10^{3}$ \\
Proteus mirabilis & $4.1 \times 10^{3}$ & $3.7 \times 10^{3}$ \\
K. aerogenes & $1.55 \times 10^{3}$ & $1.1 \times 10^{3}$ \\
Ps. aeruginosa & 0 & 0 \\
\hline
\end{tabular}

Table II Attachment of bacteria to glycoprotein at $\mathrm{pH} 7.0$ and a temperature of $37^{\circ} \mathrm{C}$ (by viable count)

The results from the viable counts (Table II) show in general results similar to those obtained by nephelometry, with the strongly negatively charged bacteria again being more attracted to, or attached to, the glycoprotein.

In all cases washing the glycoprotein only slightly reduced the bacterial count.

\section{Discussion}

\section{METHODOLOGY}

The problem of the attachment of bacteria to glycoprotein has been studied by two methods, one measuring the bacteria remaining in suspension around the mucus and the other directly measuring the viable bacteria attached to the mucus. In the design of the experiments correc- $c$ tion has been made for some possible errors; it is worthwhile drawing attention to these so $\vec{\partial}$ that the value of the results can be assessed.

In the nephelometric method errors due to the natural sedimentation of the bacteria were avoided by taking counts from the top of the suspension and by the addition of glass beads $\overrightarrow{0}$ to the control to allow for bacteria trapped $\frac{C}{O}$ by the glycoprotein.

The necessity of running these experiments $\vec{\nabla}$

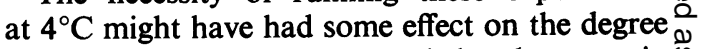
of ionisation of the bacteria and the glycoprotein ${ }^{\circ}$ but this would only be slight as ionic suppression $\vec{O}$ on the two system components would be similar. $\overrightarrow{\mid}$ The normal errors also apply of measuring ${ }_{\sigma}^{\omega}$ a suspension of viable and non-viable cells and estimating this as a total viable count. Estimating the bacteria by total $\mathrm{N}_{2}$ was not feasible, as for the purpose of these experiments viable $\omega$ counts were required to give a representative $\mathcal{N}_{N}$ picture of the attraction of bacteria to mucus. 0 The method using direct viable counts to measure ${ }_{-}$ the bacteria on the glycoprotein had one drawback $\vec{D}$ because centrifugation was essential to ensure? that all the glycoprotein was estimated. Attempts were made to correct for spin down error in this series. As fragmentation of the glycoprotein. did not matter, these experiments were run at $37^{\circ} \mathrm{C}$.

Although the two methods suffered fromō different sources of error, the general patterns of the results were similar.

\section{RESULTS}

The bacteria that are normally consideredơ pathogenic in the respiratory tract in cystic fibrosis, namely, $\boldsymbol{H}$. influenzae, Staph. aureus? and Strep. pneumoniae, had a greater affinity? for the glycoprotein than the other test organisms. This may be explained by the differing electricalo charges on the bacteria. The removal of the bacteria from the glycoprotein by washing was very difficult and it is reasonable to assume that if a sputum specimen were treated in this way‥ the loss of organisms from mucus plugs wouldN be small. The effect of washing sputum would be to remove the debris which would contain aO greater number of 'non-pathogens' than truew pathogens. On culture of the washed sputum an increase in the proportion of pathogens wouldo be expected.

The consequences of the differential attach $\stackrel{?}{-}$ ment of bacteria to mucus may well be of importance in treatment, especially considered to $\frac{0}{\mathbb{D}}$ gether with the differences in the degree of binding? of various antibiotics to hog gastric mucus demonstrated by Saggers and Lawson (1966).

Work on this aspect in a glycoprotein-antio biotic and pus cell antibiotic system is at theo moment being done in this laboratory and wilk. be reported in due course. 
It should also be borne in mind that specific mucolytic agents that attack glycoprotein would release pathogenic organisms from the glycoprotein, thus making them more susceptible to attack from antibiotics. It should not be forgotten, however, that in the absence of effective antibiotic therapy, mucolytics may increase the spread of the infection.

\section{References}

May, J. R., and Delves, D. M. (1964). The survival of Haemophilus influenzae and pneumococci in specimens of sputum sent to the laboratory by post. J. clin. Path., 17, 254-256.

May, J. R., and Delves, D. M. (1965). Treatment of chronic $\stackrel{\overrightarrow{2}}{\overrightarrow{2}}$ bronchitis with ampicillin: some pharmacological ob- 으. servations. Lancet, 1, 929-933.

Saggers, B. A., and Lawson, D. (1966). Some observations on the penetration of antibiotics through mucus in vitro. J. clin. Path., 19, 313-317.

Saggers, B. A., and Lawson, D. (1968). In vivo penetration of antibiotics into sputum in cystic fibrosis. Arch. Dis. Childh., 43, 404-409.

Shiota, K. (1967). Vth International Congress of Chemotherapy. Vienna. A1-5a/3L.

\section{The March 1970 Issue}

\section{THE MARCH 1970 ISSUE CONTAINS THE FOLLOWING PAPERS}

Immunological and histological studies in primary biliary cirrhosis S. HADZIYANNIS, P. J. SCHEUER, T. FEIZI, R. NACCARATO, D. DONIACH, AND S. SHERLOCK

Clinical evaluation of the urinary sediment after renal allotransplantation M. PAPADIMITRIOU, G. D. CHISHOLM, A. E. KULATILAKE, AND R. SHACKMAN

Identification of mineral particles in pneumoconiotic lungs W. J. HENDERSON, J. GOUGH, AND J. HARSE

Elastic vascular sclerosis of mesenteric blood vessels in argentaffin carcinoma P. P. ANTHONY AND R. A. B. DRURY

Histopathology and the future D. L. GARDNER

Immunoglobulins in Jamaicans and Nigerians with immunogenetic typing of myeloma and lymphoma in Jamaicans H. MCFARLANE, A. TALERMAN, AND A. G. STEINBERG

Studies on iron metabolism in sickle cell anaemia, sickle cell haemoglobin $\mathrm{C}$ disease, and haemoglobin $C$ disease using a large volume liquid scintillation counter BELA RINGELHANN, FELIX KONOTEY-AHULU, AND SILAS R. A. DODU

Glucose-6-phosphate dehydrogenase deficiency and chronic haemolysis in an English family E. C. HUSKISSON, B. MURPHY, AND CAROLYN WEST

Reduction in blood platelet size with increase in circulating numbers in the postoperative period and a comparison of the glass bead and rotating bulb methods for detecting changes in function

J. B. ENTICKNAP, T. S. LANSLEY, AND THELMA DAVIS
Estimation of platelet adhesiveness on whole blood and platelet-rich plasma SIDNEY SHAW, GEOFFREY D. PEGRUM, AND SYLVIA WOLFF

Investigations and preparation of fibrinogen-coated tanned sheep red cells P. C. DAS

Atypical leukaemia of long duration with monoclonal hypergammaglobulinaemia

M. CONSTANTOUlaKIS, E. PHOCAS, AND

G. THEODOROPOULOS

Comparison of the indirect fluorescent antibody test with agglutination, complement-fixation, and Coombs tests for Brucella antibody JOAN M. B. EDWARDS, AGNES J. TANNAHILL, AND C. M. PATRICIA BRADSTREET

Some bacteraemias encountered in hospital practice NUALA CROWLEY

A simple diagnostic milk medium for Pseudomonas aeruginosa M. R. W. BROWN AND J. H. SCOTT FOSTER

Measurement of mercury in human urine $D . M$. GOLDBERG AND A. D. CLARKE

\section{Technical methods}

Multispot immunofluorescence: A simple semiauromatic method of processing large numbers of tests P. O'NEILL AND G. D. JOHNSON

Single-channel AutoAnalyzer modified to provide two channels G. B. P. INGRAM

Letters to the Editor

Copies are still available and may be obtained from the PUBLISHING MANAGER, BRITISH MEDICAL ASSOCIATION, TAVISTOCK SQUARE, W.C.1. price 21s. 